\title{
Are Tea Smallholders' Farmer Organisations in Sri Lanka Focused Towards Sectoral Issues? A Review on Present Status and Way Forward
}

\section{K.G.J.P. Mahindapala}

\section{Abstract}

Smallholders are the key contributors in the Sri Lankan tea industry, which brings much needed foreign income to the county. There has been ambiguity among the stakeholders about the road map to be followed by the tea farmers' organisations in Sri Lanka. This review attempt to discuss the critical issues in tea smallholding sector, the present status of Farmer Organisations (FOs) and their contribution in resolving the issues and to provide some insights on how they can be strengthened. This review is developed through the analysis of available literature and secondary data. The literature shows that FOs, in the world, has gone many miles in the paths of member empowerment, production support, processing, financing, extension service, welfare and marketing. Tea Small Holding Development Societies were formed by the government of Sri Lanka focussing on similar objectives, particularly agriculture development, marketing facilities, welfare activities and providing credits and inputs.

Low productivity, low household income, poor adoption of technologies, small land size, senility of tea, poor service receiving from the state agencies, weak infrastructure facilities, labour issues and low prices for green leaf tea are the interconnected critical issues faced by the smallholders at present and which comes under the purview of the above objectives. Evidence, however, shows that tea sector farmers' organisations (Tea Smallholding Development Societies - TSDS) have not been able to achieve their expected gole.

Some strategic approaches adopted by Indian Farmer Producer Companies, Japanese Agriculture Cooperatives and Kenyan Tea Development Agency such as shifting into the market orientation, value addition, product diversification, integration of services, collective approaches, strengthening of the federated structure should be considered in developing TSDS.

This approach is coherent with social enterprise concepts. Non-profit organisations integrate for-profit activities to strengthen their social mission to meet the current socio-economic challenges. Thus, based on the evidence, the author believe that TSDS should be transformed as social enterprises.

Keywords: Farmer Organisation, Market-oriented activities, Sri Lanka, Social enterprise, Tea smallholders
Tea Research Institute, Low-country station, Ratnapura

prasanjithjm@gmail.com 


\section{Original Article}

\section{INTRODUCTION}

Tea, being the leading foreign exchange earning crop in Sri Lanka, provides greater strength to the national economy and livelihood of people in the tea industry while generating numerous benefits to the society (Anon, 2017a). In terms of the size of holdings, three main segments could be identified in the Sri Lankan tea industry. They are smallholders, owning less than 10 acres (4 ha) of land, proprietary estates, owing to a land size between 10 - 50 acres (4-20 ha) and corporate sector estates having over 50 acres (20 ha) of land. Smallholders are the key contributors in the tea industry as they produce over 70 percent of the total production, and they hold over 60 percent of the tea land (Anon, 2017b).

Technology transfer mechanism and the development activities in the tea smallholding sector are handled by Tea Small Holdings Development
Authority (TSHDA) which was established in 1977 under the act no 35 of 1975 and act amended in 2003 (No.34). The extension mechanism in the smallholding sector mostly similar to the "Agriculture Knowledge System model", Where Tea Research Institute (TRI) does the technology development and TSHDA provide the extension service to the smallholders. Figure 1 shows the links between smallholders and other entities to meet their needs in the crop production and marketing process. Tea Inspector (TI) is the grassroots level extension agent who supposed to facilitate smallholders in the respective range (Obeysekara, 2009).

The scope of this paper is to discuss the critical issues in tea smallholding sector, the present status of farmer organisations and their role and finally a way of strengthening the FOs to empower the tea growers and to address the issues.

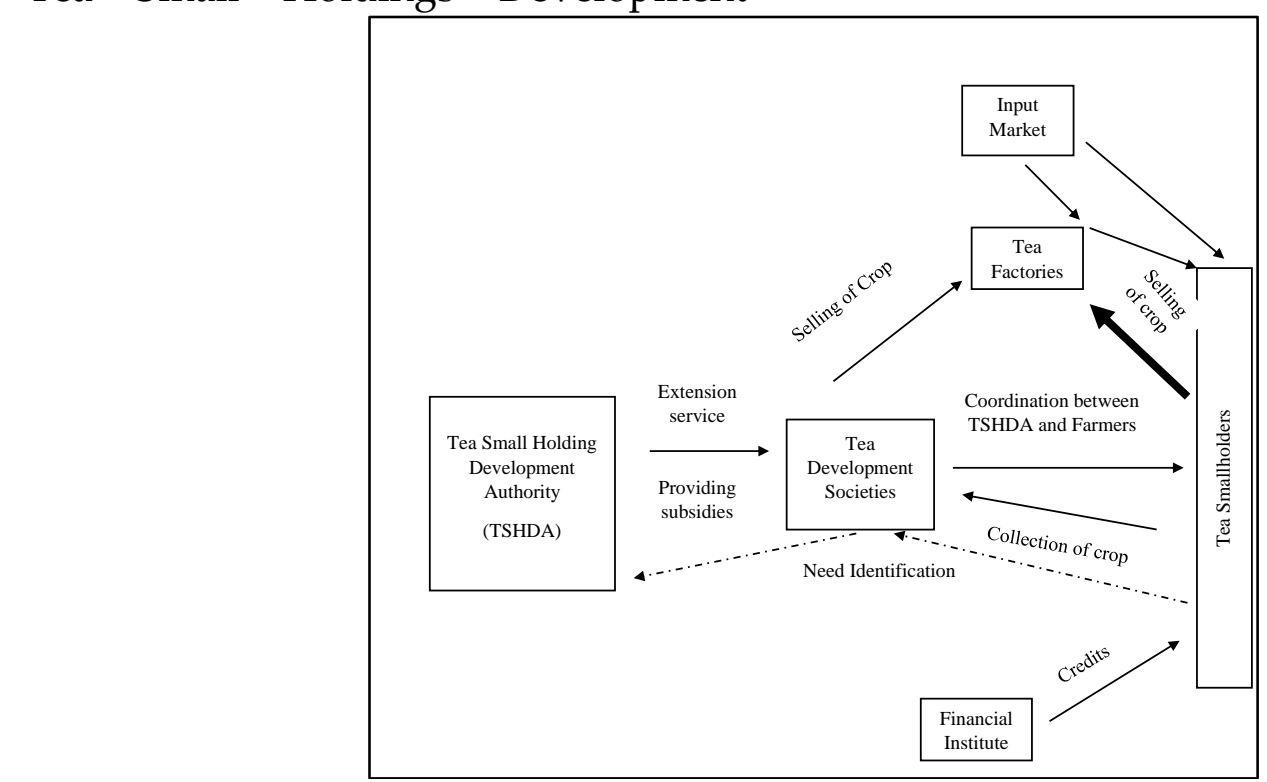

Figure 1: Links between smallholders and other entities

Source: Adopted from Obeysekara, 2009, p.168. 


\section{Original Article}

\section{METHODOLOGY}

\section{Theoretical Framework}

The private sector (for-profit sector), public sector and Non-profit sector are the main three types of enterprises operated in the world (Cyrus pattern,2017). Non-profit organisations are voluntary organisations which primarily work on social goals (ADB, 1998; Speer and Perkin, 2002). These non-profit organisations usually focus on social-related aspects. However, dealing with recent challenges, non- profit organisations have taken steps to integrate business functions with their social activities, and such organisations are called social enterprises (Gunn, 2004). Social enterprises engage in business activity to strengthen their social mission. Thus, Social enterprises focus on two fundamental factors -Economic and social while attempting to achieve sustainability (Weerawardana and Mort, 2006; Abeysekera, (2019). This concept is a multidimensional concept and can be illustrated as Figure 2.

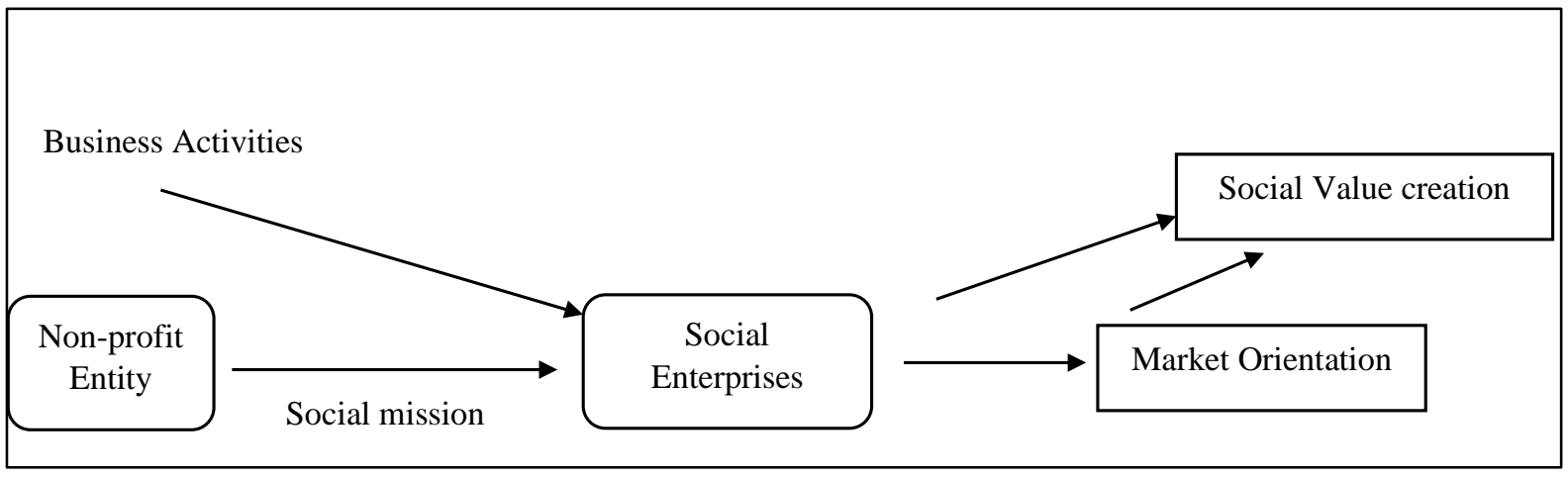

Figure 2 : Illustration of Social enterprise concept with multidimensional properties.

Source: Adopted from Gunn (2004); Weerawardana and Mort, (2006)

Farmer organisations are predominantly non-profit organsations. However, in the neoliberal economic context, the FOs can be assessed using the social enterprise concept, as illustrated in Figure 2.

The facts and information were collected through the literature survey, extracting from the published research and review articles. The secondary data were collected from annual reports, statistical bulletins published by Tea Smallholding Development
Authority, Sri Lanka Tea Board, Central Bank and Ministry of Plantation Industries to build up the logical arguments. In some instances, facts were collected through personal communication with expert persons, when there is an information gap. Legislative acts and gazettes of the government of Sri Lanka and certain websites were also referred to gather information. The unpublished data available with the author were also used in this review. 


\section{Original Article}

\section{REVIEW AND ANALYSIS}

Critical Issues in Tea Smallholding Sector

The productivity of tea smallholding sector (1872 kg/MT/ha) in Sri Lanka is high when compared with corporate sector (975 kg/MT/ha), and which is comparatively low when compared with Kenya and North India (Anon, 2016a; 2016b). For this variability, although some environmental factors may have an effect which is on productivity trends of Sri Lanka and India. Figure 3 shows that it is a continuous pattern. There is a yield gap exists between potential yield
(2500-3000 kg/MT/ha for most of vegetatively propagated (VP) cultivar and smallholder yield for many reasons such as senility of tea, poor adoption of good agriculture practices, land degradation and prevalence of pests and diseases. Furthermore, the 'break-even yield' is estimated to be in the range of $1300-1500 / \mathrm{kg} / \mathrm{ha} /$ year (personal communication with Shamale, H.W, Economist, TRI, 2020, March). Thus, there is only a narrow gap between the current average yield and the break-even yield. This too indicates the instability of the current average yield.

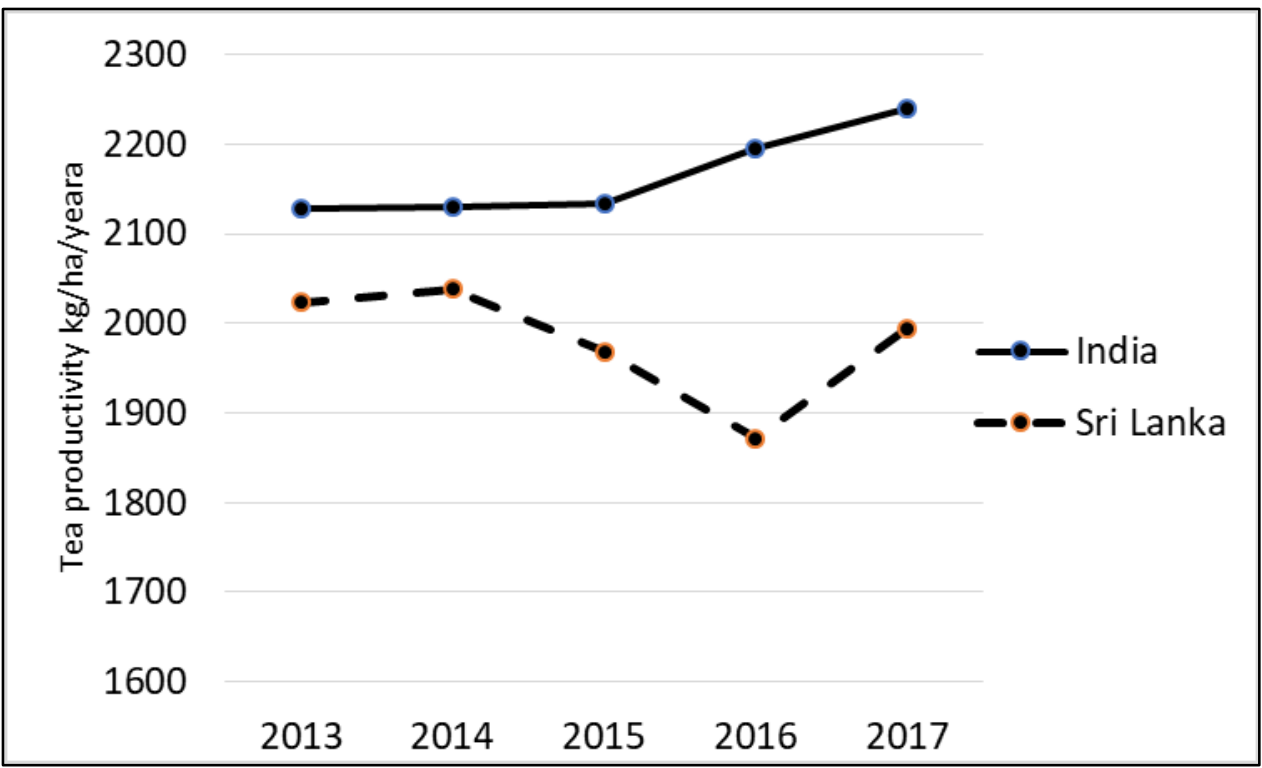

Figure 3: Tea productivity trends of Sri Lanka and India.

Source: Calculated based on the data available in - Statistical information for plantation crop, Ministry of Plantation Industries.

Senile tea should have been replaced with new plants. The majority of the smallholders (80\%) have less than 1 ac land (Anon, 2005) and they hesitate to go for replanting of tea due to fear of affecting their only income source.
Moreover, unlike in many other crops, tea replanting is a huge cost (approximately Rs. 1 million/ac) involving operation (Jayakody, 2001; Personal communication with Shamalie, H.W, the Economist, TRI 2020, March) that also cause to delay 


\section{Original Article}

their replanting operation. This is going like a vicious cycle illustrated in Figure 4 .

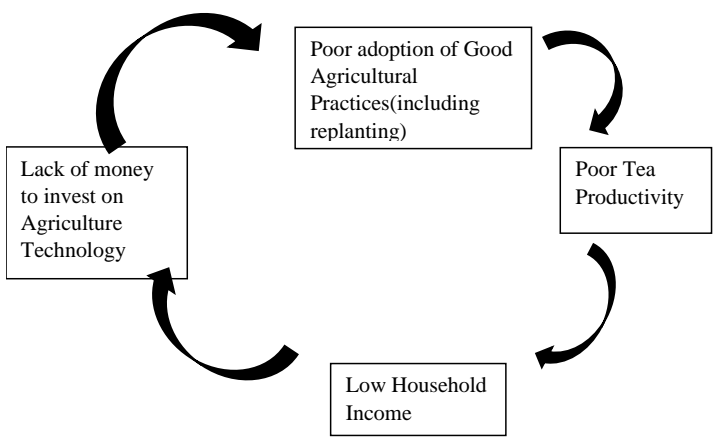

Figure 4: Vicious cycle on poor tea productivity of smallholders

Source: Constructed by the author, based on the literature and experience

However, in addition to the lack of capital, there are many factors such as lack of knowledge, poor infrastructure, individual factors of farmers and social factors influences the adoption of technologies (Rogers, 2003; Bandura,1977; Hornik, 1988). In this context, extension agent (Tea Inspector-TI) also has a very vital role in the development of the smallholders particularly improving their knowledge on agricultural technologies and motivating the farmers (Herath, 2010). However, there are only 157 TIs (Anon, 2016b) to look after about 400,000 smallholders and which means that Extension Officer to Farmer ratio is over 1:2700 which lead to delivering of poor service, to the tea smallholders and eventually, this condition developed into a severe gap between farmer and extension worker (Obeysekara, 2009). A study showed that smallholders in remote areas have minimum access to government extension services (Perera, 2014). The adoption level of growers with respect to some of the cultural practices such as pruning, weed management, pest and disease management and soil moisture conservation is less than 60 percent according to a study conducted in randomly selected three rural areas in Matara district, (Jayamanna et al., 2002). A sample survey conducted by TSHDA in 2008 revealed that 92 percent of smallholders used old tea cultivars (TRI 2000 series), which introduced in the early 50s (Anon, 2008). This poor technology adoption pattern of the smallholders was also observed in the recent studies done in many different regions (Mahindapala et al., 2019 a; Mahindapala et al., 2019b; Mahindapala et al., 2019c; Mahindapala et al., 2020). Before the 90 s, there was a greater concern that the smallholders were being exploited by the tea manufactures. However, with the introduction of green leaf price formula, by the Sri Lanka Tea Board, smallholders are protected to a certain extent (Ganewatta and Edwards, 2000). However, some of them still have some concerns about the process of marketing of green leaf (Banerjee, 2012). Sri Lanka exports almost 65 percent of the export quantity of tea as bulk tea, which has low FOB price when compared with value-added products (Anon, 2016a) and accordingly it can be argued that smallholders do not get the real prices (potential price) due to failing in value addition. Unless they have the 
controlling ability in value addition, processing and marketing- like in Kenyan tea smallholders (Kenyan Humen Right Commission, 2008), they will not get the real prices. The labour availability is also an issue for a certain segment of smallholders, particularly those who cannot depend only on family labours. As per the survey done in Ratnapura district, where onefourth of smallholders are living, smallholders are suffered by about 30 percent labour scarcity (Lavanya, 2018).

The issues discussed in the above can be categorised into the crop production-related (Inputs and extension), financial, resource-related (land and labour) and market-related. Hence, it is necessary to empower the tea smallholders through a collective approach to address these issues. In many countries, Farmer-Based Organisations (FBO) were formed to resolve the similar issues faced by small farmers. (Barham and Chitemi, 2009).

\section{Farmer-Based Organisations}

The ${ }^{1} \mathrm{FBO}$ is an entity that represents the farmers in a given geographical area and mainly deals with agriculture enterprise-related needs of the member farmers (Esham, 2012). It is a voluntary membership organisation

\footnotetext{
${ }^{1}$ It appears that some authors used two names of FBO and FO (Farmer Organisation) interchangeably. However,according to Esham (2012) FBO has a broad meaning, and which consist of two different types - namely farmer organization and farmer companies.
}

created to achieve the economic benefit of farmers and to provide services, related to farming and marketing of their products (Kassam et al., 2011). Usually, the FBO has well-defined membership, and their principal function is to provide the service to the members (Stockbridge et al., 2003). FBO has organised structure, a purpose for gathering and attempt to achieve a standard set of objectives. It is an essential entity to empower the rural farmers, poverty alleviation and eventually uplift their living standards. FOs facilitates to buildup network of relationships within the organisation (among the member farmers) and as well as with individuals or entities at outside the organisation, which provide relatively higher benefits than working alone (Ostrom, 2000). These interpersonal networks are considered as social capital (Dasgupta, 2002). Therefore, FO can also be understood as an avenue for social capital.

Depending on the size of the membership, nature of the service provided and level at which they function, FO can be small, medium or large scale and can be of the form of, (i) Farmer Interest Group (ii) farmer association/federation/Unions cooperatives (Kassam et al., 2011). Chamala and Shingi (1997) divided the FBO into two groups as communitybased with resources oriented and commodity-based with marketoriented. Fist type mainly deals with inputs and other resource needs of its 
members. The second group is specialised into a specific commodity and more concern on value addition and selling their products in the competitive markets. However, in the present complicated context, some FBOs having a mixture of characters from each group.

In addition to the poverty alleviation, the formation of $\mathrm{FO}$ can have economic objectives such as the scaling of economies, reduction of transaction and coordination cost, accessing to the capital, risk management and building up of countervailing power. (Spileman and Bernard, 2009; Datta, 2004). Further, today well-developed FOs undertakes multiple activities for the benefits of their members (Rondolt and Colin, 2007; Terebbin and Hassler, 2012). They are:

1. Organising activities

2. Production support.

3. Marketing related activities (processing, value addition, products transporting, Wearhouse facility, linking of markets)

4. Loans and subsidies.

5. Extension, Education, Training.

6. Welfare.

7. Management of resources

8. Provides inputs for policy formulation.

Due to the failure to provide proper services to smallholders, the government amended the TSHDA Act to establish 'Tea Smallholder Development Societies'.

Farmer Organisation in Tea
smallholding Sector

State Promoted FOs

These FOs are called as Tea Smallholding Development Societies (TSDS). According to the act (No. 36 of 1991 and No. 21 of 1997) and subsequent gazette (No. 878/15 of July 1995) notification, TSDS were registered in the TSHDA. They systematically came into operation in 2000. These societies are established to achieve the following objectives (i) To develop tea smallholdings (ii) Provide the marketing facilities for grower's production (iii) to promote the economic and welfare activities of members (iv) Facilitate the members in the area of credits and inputs (v) engage in development projects.

The entire Tea Smallholding Development Society (TSDS) system looks like a federated structure with three tiers (Figure 3). At the village level there are Rural Tea Societies (RTS) and there may be several RTSs for the Tea Inspector region and holding density of the area (Obasekara, 2009; Cyril, 2014). RTS is managed by an executive committee which comprises of President, Secretary and Treasurer and other eight representative members appointed bi-annually from the members vote. The three principal officers of each RTS in a particular district are combined to form the district level organisation. The National level organisation is made up 


\section{Original Article}

ISSN: 2279-3933

of principal officers of each district

details of societies in each district.

organisation, and Table 1 shows the

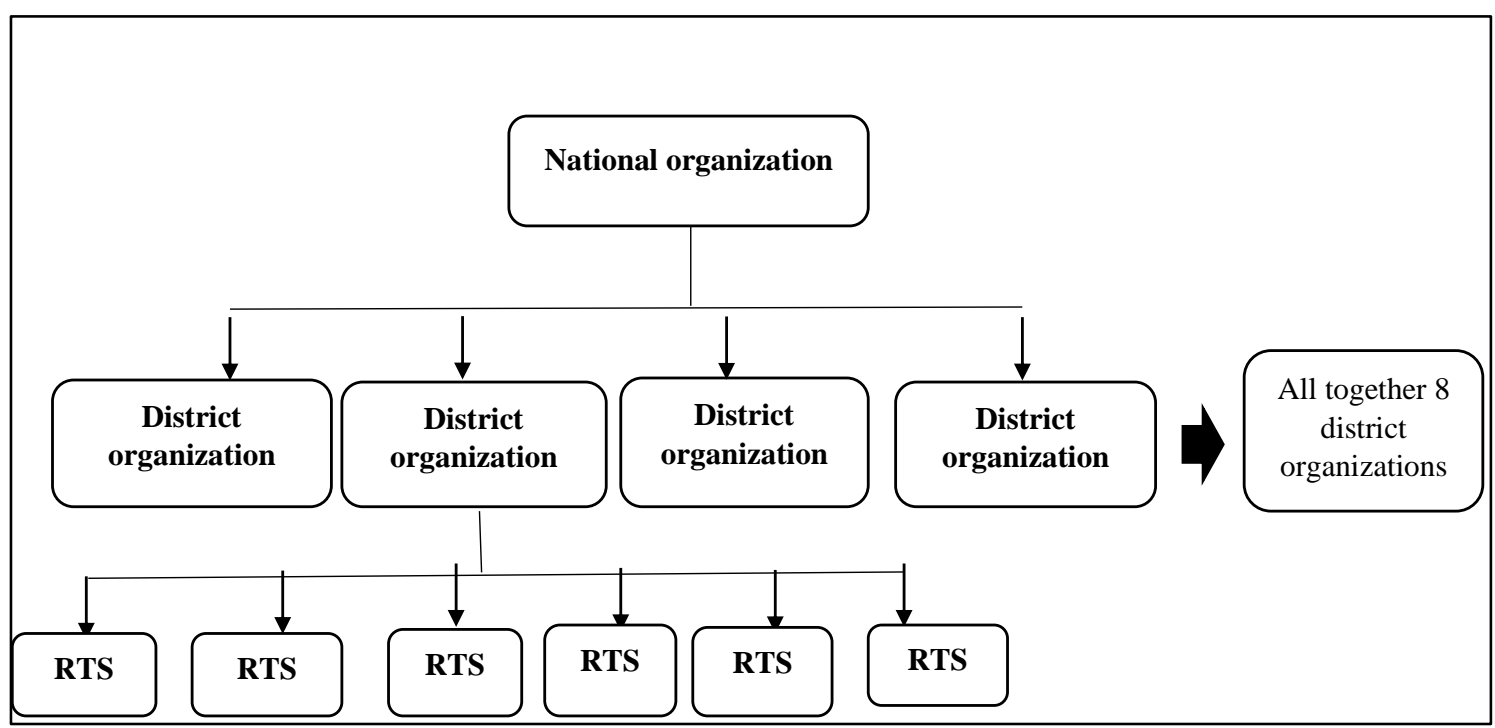

Figure 3: Organisational structure of Tea societies (TSDS)

Source: Adopted from Cyril (2014).

Table 1: Details of societies in different regions

\begin{tabular}{llr}
\hline DISTRICT & $\begin{array}{l}\text { NO. } \\
\text { OF } \\
\text { RTS }\end{array}$ & $\begin{array}{l}{ }^{*} \text { TOTAL NO. OF } \\
\text { SMALLHOLDERS }\end{array}$ \\
\hline $\begin{array}{l}\text { Matara- } \\
\text { Hambantota }\end{array}$ & 166 & 65,359 \\
Galle & 208 & 81,491 \\
Kalutara & 89 & 35,908 \\
Ratnapura & 273 & 92,038 \\
Kegalle & 119 & 18,893 \\
Kandy- Matale & 133 & 25,663 \\
Badulla & 156 & 28,735 \\
Nuwaraeliya & 175 & 21,968 \\
Total & 1319 & 370,842 \\
\hline
\end{tabular}

Source: Obeysekara, (2009)

$\left({ }^{*}\right.$ Not necessarily be the members of RTS)

TIs are closely associated with RTSs and required to monitor their activities.

As mentioned in section 3.3.1, these RTSs are supposed to carry out functions related to marketing, welfare, smallholding development work and facilitative role in providing inputs and credits. However, in a real situation, most of the activities have been neglected. Based on their activeness RTSs were graded as A, B, C, D and E, and only a few RTSs belonging to ' $\mathrm{A}$ ' class are involved in collecting green leaf and supply to the factory. Since most of the TSDS does not employ the income generation mechanism, they do not offer the members' welfare service. The majority of the RTSs act as intermediaries between the farmer and the Tea Inspector (TI) and facilitate both parties in disbursing subsidies and other assistance as and when available. Although RTSs coordinate the extension, training and field inspection activities with TI which are not happening at an optimum scale due to poor commitment. Except for a few TSDS, most RTSs does not facilitate obtaining the inputs or credits (Mahindapala et al., 2020). 


\section{Original Article}

Tea Producers Cooperative and FOs Promoted by Agribusiness Entities

In addition to the state promoted FOs, A tea grower-owned cooperative and few contract grower groups affiliated to tea processing firms are also found in the smallholding sector, and they also can be considered as FOs. Morawak Korale Tea Producers Cooperative Society (MKTPCS) is the only cooperative belonging to a teagrowing community in Sri Lanka. It was established in 1953 to collect and process the tea green leaves of the smallholders in Deniyaya region in order to prevent the exploitation by surrounding tea factory (Author, 2020, unpublished data). The cooperative provides reasonable service to the members in the area of the marketing of the production of the members, production support and welfare. Further, it was revealed that the members of the two farmer groups affiliated to tea processing firms in Matara district are benefited through various activities implemented by agribusiness enterprises (Author, 2020, unpublished data). However, these organisations (both cooperatives and Farmer groups) are confined in too small pockets. According to statistics, only four cooperatives are registered as tea producing cooperatives (one in Uva province and three in southern province) but only two are in operation. Thus, their contribution to the national level in terms of the coverage is insignificant.

\section{Present status of TSDS}

Bandula et al. (2016), has done a study to evaluate whether these societies were able to make any quantifiable impact on tea smallholders in Matara district. Their findings revealed that there was no significant improvement in tea smallholding sector in the study area as because of the introduction of TSHDSs. This finding is negating the positive results on FBOs seen in the Indian and Japanese context. The particular study further revealed that only 27 percent of the members are satisfied with the activities of FOs. According to the results, the majority of the members look the RTS as a means of facilitating body for channelling the subsidies and advice, and they do not perceive the other advantageous of FOs.

Some indicators also supported the above findings. TSHDA has never been able to achieve the minimum replanting target (rate of $2 \%$ ) even after the establishment of the society (Figure 4). Figure 5 shows the overall tea production of smallholders since 2000 and is on a declining trend. As shown in Table 2, there has not been seen as a significant improvement in the other key indicators compared to recent statistics with 10-years back. This condition is possibly due to poor adoption of technologies and senility of tea bushes due to low rate of replanting. 


\section{Original Article}

\section{5}

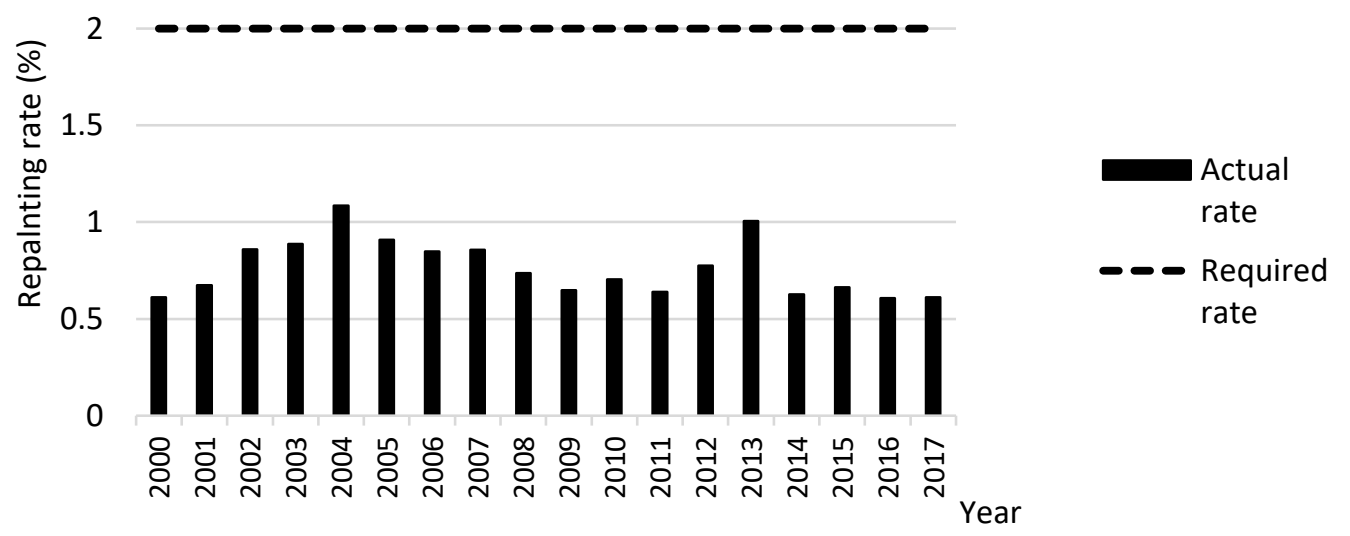

Figure 4: Minimum required replanting rate and actual replanting rate in the smallholding sector Source: Based on the author's analysis of secondary data available in Statistical Information of Plantation Sector, 2018 and 2012, Ministry of Plantation Industries

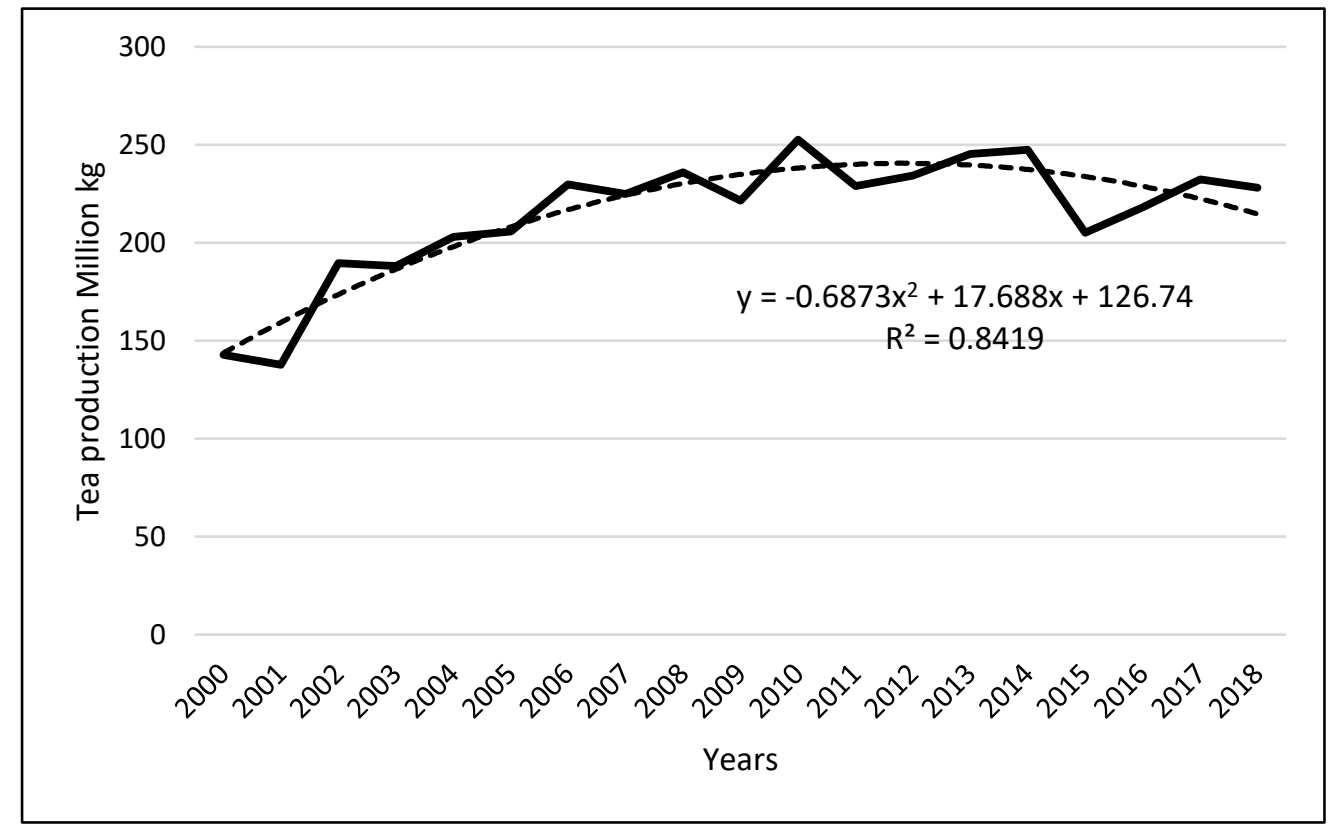

Figure 5: Total tea production recorded in the smallholding sector.

Source: Statistical Information of Plantation Sector, 2019, Ministry of plantation industries.

Table 2: Performance indicators in the smallholding sector in 2007 and 2017

\begin{tabular}{lrrrrrr}
\hline Year & $\begin{array}{l}\text { Productivity } \\
\text { (kg/ha/year) }\end{array}$ & $\begin{array}{l}\text { Production } \\
\text { (million kg) }\end{array}$ & $\begin{array}{l}\text { Indicator } \\
\text { (ha) }\end{array}$ & $\begin{array}{l}\text { Infilling } \\
\text { (ha) }\end{array}$ & \multicolumn{2}{l}{$\begin{array}{l}\text { Extent } \\
\text { (ha) }\end{array}$} \\
\hline 2007 & 2039 & 224.8 & 1024 & 41.28 & 119,492 \\
\hline 2017 & 1995 & 232.4 & 748 & 45.13 & 116,492 \\
\hline
\end{tabular}

Source: Annual reports TSHDA 2008 and 2017

Further, based on the perception of Tea Inspector - the key extension agent of Tea smallholders, RTS are not performing well due to poor 


\section{Original Article}

leadership, lack of commitments of members and executive committee members, issues in trustworthiness, status and attitudes of the members, and the effect of some external factors (Mahindapala et al., 2020). It was also revealed that the self-reliance status of the RTS is poor as they mainly depend on TIs and highly sensitive to the government aids. The majority of RTSs are not goal-oriented, and none of the organisation involved in value addition, processing and marketing (Mahindapala et al., 2020). Therefore, they are purely non-for-profit (NFP) entities and community-based resources-oriented organisations.

Moreover, the development of smallholdings is one of the objectives of the establishment of TSDS. Yet, it is not reflecting in the technology adoption levels of the majority of the growers. According to the recent studies, it was revealed that technology adoption of smallholders in the different region was at suboptimal level (Mahindapala et al., 2019a, Mahindapala et al., 2019b, Mahindapala et al., 2019c). If society could have made an effective intervention, this would not have happened. Therefore, the production support role of these societies is appeared to be questionable.

The approach adopted by the state to develop farmer organisations, and through them improve the technology transfer process and other related support required to improve the production of green leaf tea of growers and associated changes in the industry has not been materialised. It appears that there is a shortfall in expected developments both at the organisational (TSDS) and individual tea grower levels. The development role expected through the societies appears to have failed to realise.

However, to enhance the status of these societies is prime important, and therefore, it is essential to study the success cases in smallholding sector in elsewhere and explore the possibility to adapt them into local condition. In fact, the study of Bandula et al. (2016) found that 75 percent of the members as well as 85 percent of the nonmember in the study sample, were of the opinion that RTS could be transformed as a productive entity which can make an impact on their lives.

\section{Way Forward}

When searching for success model to learn lessons, Indian Farmer Producer Companies (FPC), Japanese Agriculture Cooperatives (JAC) and Kenyan Tea Development Agency (KDTA) are unescapable examples.

Indian FPCs are widely recognised as successful FBOs. The Companies Act of 1951 was amended by the Government of India to facilitate the establishment of farmer companies, and subsequently, many farmer producer organisations have transformed into FPCs (NABARD, 2019). The FPC is a hybrid of private 
companies and cooperatives (Terribin and Hassler, 2012). This FPCs are categorised into three distinct groups based on the level of business orientation or involvement of forprofit activities (Terribin, 2014). However, TSHDS are hardly businessoriented ones, and they do not involve in processing, branding, product diversification and marketing. But it is necessary to be involved in these processes rather than selling the primary product (Green leaf) to receive the maximum benefits to their production. These TSHDS has to undergo several changes in its structure. Traditional members have to turn into shareholders. In the Indian FPC, value addition process and marketing are handled by the externally recruited professional managers (Terrain and Hassler, 2012). A similar mechanism should be thought for local setup as such skills are hard to find within the rural tea smallholders. A similar strategy is implemented in Kenya, where tea smallholders formed a company known as KDTA and which runs 63 tea factories (Monroy et al., 2013). At the initial stage, these organisations may require the 'handholding support for' a certain period that includes financial and technical assistant until they establish, where government intervention is required as in India (Salophen, 2016). In fact, this type of model has already been successfully tested in the smallholding sector in one of the regions in Sri Lanka. The shareholders of Morawak Korale Tea
Producer Cooperative Society receive a vast array of benefits including bonus, welfare and extension service and credit facilities for the development of tea estates (Aurthor, 2020 unpublished data). Indian FPC and JAC promote the field level collective activities as well as labour sharing (Ojha and Raju, 2018; Rajarathna, 2007), which provide a room for sharing of technical knowhow as well. Even though smallholders experience the shortage of labour, TSHDS did not develop a mechanism for labour sharing and which should be required to consider. The JAC is divers FO with a threetiered federated structure to provide the vast array of services to the farmers, including credit facilities, insurance and extension service (Esham, 2013). TSHDS also has a threetiered federated structure (Figure 3), such as rural, district, and national levels but lacks such an integrated service model and active formal coordination between the layers. In the Japanese system, Primary cooperatives are composed of two types of members such as regular members and associate members depending on the type of cooperatives. Regular members are the person who engages with farming activities, and associate members are non- farmers. Allowing non-farmers to join the JAC help to increase the share capital status and bring more ideas to the organisation, which facilitated them to go for a diverse business (Godo, 2009; Kazuhito, 2013). 
Presently, only the tea smallholders are allowed to join rural tea societies. However, to improve the share capital of the rural tea societies, it would be very essential to relax the restriction imposed for ownership/membership for outsiders. In fact, it is not a strange thing for Sri Lanka as the Kapruka Societies established in the coconut sector (under the act No. 31 of 2005) has entertained this provision. About sixteen societies perform well (personal communication with LWAMUS Kumara, National Coordinator of Kapruka Fund, 20122016, on 2020 March). According to Paget - Clerk (1999) Collective group action, leadership, commitment, community mobilisation, participatory decision-making, value addition, marketing of product are the key elements contributed to the success of JAC and thus such factors need to be considered.

Perhaps, the Indian FPC would have been influenced by Gujarat Cooperative Milk Marketing Federation Ltd (Amul) which had been established in 1946 Ananda, of Gujarat state as a small cooperative (Ananda Milk Producers Cooperatives) to prevent the exploitation of dairy farmers. Now it was evolved as the largest food processing company in India and produce milk food under the brand name of Amul (Manikutty, 2002). This 'Amul model', is considered as a three-tiered structure and consist of the village-level dairy cooperatives societies $(18,700)$ district- level milk producers' cooperative unions (18) and state-level federation (Gujarat Cooperative Milk Marketing Federation) where farmer controls the production, processing and marketing with the support of professional management.

When it comes to Kenyan Tea Development Agency (KDTA), it is owned by over 550,000 shareholder farmers, and they are affiliated to the nearest tea factory. The farmers' tea green leaves are collected nearby collecting centres and transported to the regional factory. The Farmers receive a comparatively higher price for their products and receiving extension services and inputs. Hence, this is a commodity-based, market and service-oriented FC. Integration of crop production, processing, marketing, and providing better services for the smallholders and inclusion of farmers in decision making could be the reasons for the farmer company's relative success.

From the above success cases, we can draw some lessons for Sri Lankan TSDS. The main difference we have observed was JAC, Indian "FPC" and KTDA are widely engaged in forprofit activities, whereas TSDS hardly engage in such activities. Moreover, with professionals' help, various value-added activities such as processing, grading, branding, storage and marketing have been carried out FOs in the above success cases. Hence, farmers get high prices for their produce. But TSDS has not entered 


\section{Original Article}

into such commercial activities. Therefore, it is essential to introduce social enterprise concepts to the TSDS. To meet the recent challenges, nonprofit organisations have taken steps to integrate business functions with their social activities, and such organisations are called social enterprises (Gunn, 2004). Social Enterprises acquired business functions to reinforce and expand their social mission in a sustainable manner (Spreckley, 1981; Dees, 1998; Mort et al., 2003).

\section{FINAL THOUGHTS}

The farmer organisation is an essential entity to empower the rural farmers, and eventually uplift their living standards. Farmers have many advantageous being in an FO than working alone. There is ample evidence that FOs can be used as an excellent tool to empower small farmers in a variety of ways. Tea smallholding sector statistic indicates that the sector is not in good shape. Yet it seems that TSDS has not intervened adequately to arrest these issues. In this paper, the author argued that the sector's productivity was greatly affected due to poor adoption of agriculture technologies, and it has gone into a vicious cycle. Furthermore, effective farmer organisations could have dealt with such matters and motivate members to get better returns and break this cycle. FO has transformed as farmer companies or rather change their orientation into the market in response to the neoliberal economic changes. Such organisations attempt to process their product and make value addition instead of selling primary products. Therefore, those success examples suggest that strategic approaches such as value addition, product diversification, integration of services, collective practices and strengthening of federated structure could be used to advance the TSDS. This approach is non-other than the social enterprise concept where nonprofit organisation integrates for-profit activities to strengthen their social mission for their sustainability (Dees, 1998; Gunn, 2004; Weerawardana and Mort, 2006). Based on the empirical evidence, the author strongly believes that TSDS should be transformed as social enterprises. Further, individual factors and group dynamics also have a bearing on the performance of the FOs. However, in-depth scientific investigation on all these factors is necessary before adopt necessary changes.

\section{References}

Abeysekera, R. (2019). Social entrepreneurship: concepts and research areas, Sri Lanka Journal of Management Studies, 1(2), 29-42.

ADB. (1998). Cooperation Between Asian Development Bank and Nongovernment Organizations: Our framework-Policies and Strategies. https://www.adb.org/publications/polici es-strategies-and-plans? page $=37$

Bandula, G. G., Abeywickrama, L. M., \& De Zoysa, M. (2016). Tea smallholders' perceptions and experience with tea smallholdings development societies (TSHDS) in Matara district of Sri Lanka, 
Tropical Agriculture Research and Extension, 19(2), 222-227.

Bandura, A. (1977). Social learning theory, Upper Saddle River, NJ, Prentice-Hall

Banerjee, B., (2012), Contribution of smallholders to the tea sub-sector and policies required to enhance their livelihood, Intergovernmental Group on Tea, Twentieth Session, Committee on Commodity Problems Colombo, Sri Lanka.

Barham, J., and Chitemi,C., (2009), Collective action initiatives to improve marketing performance: lessons from farmer groups in Tanzania, Food Policy 34, 53 59.

Central Bank of Sri Lanka. (2017). Annual report. Colombo: CEB.

Chamala, S. and Shingi P. M. (1997). Establishing and strengthening farmer organisations a reference manual, Burton E. Swanson, (Eds). Published by Daya Publishing House New Delhi, 2005.

http://www.fao.org/docrep/W5830E/w5 $830 \mathrm{e} 0$ n.htm

Cyril, M.B, (2014), Presentation Made on "Tea smallholding sector in Sri Lanka" at FAO IGG annual session, Rangoon, Indonesia.

Cyrus Patten O., (2017). Non-profit Social Enterprise: Social Change in a New Economic Paradigm Graduate College Dissertations and Theses. 686. https://scholarworks.uvm.edu/graddis/6 86

Dasgupta, P. (2002) Social capital and economic performance: Analytics Mimeo, University of Cambridge and Beijer International Institute of Ecological Economics, Stockholm.

Dees, J.G., (1998). The meaning of Social entrepreneurship".

http://www.fuqua.duke.edu.

Department of Census and Statistics and Tea Small Holding Development Authority. (2005). Census of tea smallholding in Sri Lanka.
Esham, M. (2012). Lessons for Farmer Based Organisations (FBO) in Sri Lanka: Experiences from Agricultural Cooperatives (JA) in Japan A Journey in Harmony Sixty Years of Japan - Sri Lanka Relations, Karunaratne, H. D., (Eds), University of Colombo and JAGAAS, (Pp316-335)

Esham M, Kobayashi H (2013), farmer companies in Sri Lanka: Lesson from agriculture cooperatives in Japan Sage Journals 4(2), 117-133.

Ganewatta G., and Edwards G. W., (2000), The Sri Lanka Tea Industry: Economic Issues and Government Policies, 44th Annual Conference of Australian Agricultural and Resources Economics Society, University of Sydney, Australia.

Godo, Y. (2009). The changing political dynamics of Japanese Agricultural Cooperatives. International Association of Agricultural Economists Conference Proceedings, Beijing, China.

Gunn, C. E. (2004). Third-Sector development: Making up for the market. Ithaca, NY: Cornell University Press.

Herath, C.H, (2010), The Impact of Motivation on Farmers Decision Making on Technology Adoption with reference to Sri Lanka and the Czech Republic, 15th International Business Information Management Association Conference, at Cario Egypt.

Hornik, R. (1988), The Knowledge-Behavior Gap in Public Information Campaigns: A Development Communication View, working paper (no 110) International centre for health and development communication, Annaberg School for Communication, University of Pennsylvania.

Jayakody, J. A. A. M. (1999). Economic feasibility of tea replanting as a strategy to improve productivity in tea lands, Proceedings of the 198th Experiment and Extension Forum, TRI, Talawakellee.

Jayamanna, V. S, Wijeratne, M. Wijayaratna C. M. (2002). Adoptability of New 
Technology in the Small-Holdings Tea Sector, Journal of Agriculture and Rural Development in the Tropics and Subtropics, 103(2), 125-131.

Kassam L., Subasinghe R. Phillips M., (2011), Aquaculture farmer organisations and cluster management: Concepts and experiences - FAO fisheries and aquaculture technical paper, FAO, Rome.

Kazuhito Y, 2013, Understand the Japan Agriculture Cooperatives, Politics Economy. www.nippon.com

KHRC, (2008), A Comparative Study of the Tea Sector in Kenya A Case Study of Large-Scale Tea Estates Nairobi, Kenya. www.khrc.or.ke

Lavanya, N.L, Shyamalie, H.W. De Zoysa, M and Nadheeshani, K.W, (2018), Investigation of labour shortage: Case study in Ratnapura district, Proceedings of research symposium, University of Ruhuna.

Mahindapala, K.G.J.P., Jayarathna, S.P.A.P.K., Dayananda, H.N., Jayaweera, H. and Nishanthi, M.A.H. (2019a). investigation of debilitation of tea and technology adoption in smallholders in Mathugama division in Kalutara district of Sri Lanka, Proceedings of 12th International Research Conference of Kotelawala Defence University, Ratmalana 332.

Mahindapala, K.G.J.P., Jayarathna, S.P.A.P.K., (2019b), Technology adoption status and attributes of Tea bush debilitation in the smallholding sector in Deraniyagala divisional secretariat area, Proceedings of 75th Annual Scientific session, Sri Lanka Association for Advancement of Science, 132.

Mahindapala, K.G.J.P., Munasinghe, C.E., Jayaratna, S.P.A.P.K., Tharangika, H.B., and. Batheegama B.G.A.R.L. (2019c) Level of technology adoption and factors associated with tea bush debilitation in smallholdings in three selected ranges in Matara district, Journal of Agriculture and Value Addition,2(2) 72-83
Mahindapala, K.G.J.P., Jayathilaka, M.W.A.P., Jayawardane L.N.A.C., Kopiyawattage K.P.P. and De Mel M.P.M. (2020) Role and Capacity of Tea Societies in the Smallholding Sector in Sri Lanka: An Assessment Based on the Perceptions of Extension Officers. Tropical Agricultural Research, 31(1), 43-55.

Manikutty, S., (2002), Gujarat Co-operative Milk Marketing Federation Ltd. (GCMMF), Asian Case Research Journal, $6(2)$

Monroy L., Mulinge W., Witwer, M., 2013. Analysis of incentives and disincentives for tea in Kenya. Technical notes series, MAFAP, FAO, Rome

Ministry of Plantation Industries, (2017). Statistical information of plantation crops, , Battaramulla, Sri Lanka

NABARD (2019) Portal on Farmer Producers' Organizations. National Bank for Rural Development (NABARD), Mumbai, India.

https://nabfpo.in/images/staticFPO.html.

Obeysekara K.G.B, (2009), Agriculture extension in the tea smallholding sector in Sri Lanka, Proceedings of Agriculture Extension conference, Civayoganadan, C., (Eds), Sri Lanka Agriculture Extension Association 160-181

Ojha, Jaya and Raju, K. V.,2018 Thennala Agro Farmers Producer Company Ltd, Hopes on the Horizon: Rural women in livelihood enterprises, published by Ministry of rural development and National Rural Livelihood Mission, India. 1-8.

Ostrom E (2000) Social Capital: a pad or fundamental concept? In: Dasgupta Serageldin I (Eds) Social Capital: Multifaceted perspective, World Bank Washington DC, 172-214.

Paget-Clarke, N. (1998) Interview with Japanese Farmers' and Consumers' Cooperative Representatives. http:// www.inmotionmagazine.com/jfcg.html Motion Magazine, August.

Perera P. (2014). Tea smallholders in Sri Lanka: Issues and challenges in remote areas, 
International Journal of Business and Social Science 5(12),107-117.

Rajarathna, A. R. (2007). Roles and Effectiveness of Agricultural Cooperatives in Japan, with Special Emphasis on Organized Farm Activities, Journal of Developments in Sustainable Agriculture, 2, 192-198.

Rondot P, Collion M-H, (2007) Investing in Rural Producer Organisations (RPOS) for Sustainable Agricultural Development. RPOs Limitation and World Bank Comparative Advantage, The World Bank, Washington, DC.

Salokhe, S., (2016) Farmers producer organisation for effective linkage of small producers with the market, International Journal of Applied Research 2(10): 142-146.

Samansiri, B. A. D. and Rajasinghe, J.C.K. (2009). Agriculture extension in the tea plantation sector in Sri Lanka Proceedings of Agriculture Extension conference, 2009 Civayoganadan, C., (Eds.) Published by Sri Lanka Agriculture Extension Association. 139159.

Spielman D. J and Bernard, T. (2009) Reaching the Rural Poor through Rural Producer Organisations? A Study of Agricultural Marketing Cooperatives in Ethiopia, Food Policy, 34(1), 60-69.

Sri Lanka Tea Board. (2016). Annual report. Colombo: Sri Lanka Tea Board.

Stockbridge, M., Dorward, A. \& Kydd, J., 2003. Farmer organisations for market access. Briefing paper presented at Stakeholders Meeting on Farmer Organisations in Malawi, 18-19 June 2003, Lilongwe, Malawi.

Speer P.W., and Perkins, D.D., (2002), Community-based organisation, Agencies and groups, Vanderbilt University ins. Guthrie (Eds), Encyclopedia of Education, 2nd Edition, 431-441.

Rogers, E.M. (2003) Diffusion of innovations (5thed.) New York: Free press
Trebbin, A. and Hassler, M.,2012, Farmers' producer companies in India: A new concept for collective action?, Environment and Planning 44(2), 411427.

Tea Small Holdings Development Authority of Sri Lanka. (2008), Sample survey of tea smallholdings.

Tea Small Holdings Development Authority of Sri Lanka. (2016), Annual Report.

Trebbin, A., 2014. Linking small farmers to modern retail through producer organisations- Experiences with producer companies in India. Food Policy, 45: 35-54.

Weerawardena, J., \& Mort, G. S. (2006). Investigating social entrepreneurship: A multidimensional model. Journal of World Business, 41(1), 21-35. 